\title{
PERENCANAAN KOTA HIJAU YOGYAKARTA BERDASARKAN PENGGUNAAN LAHAN DAN KECUKUPAN RTH
}

\author{
Yogyakarta Green City Planning based on Land Use and Adequacy of \\ Green Open Space
}

\section{Amalia Ratnasari ${ }^{1}$, Santun R.P Sitorus ${ }^{2}$, Boedi Tjahjono ${ }^{3}$}

Diterima: 29 Juli

Disetujui: 19 Agustus 2015

\begin{abstract}
Abstrak: Konsep Kota Hijau adalah konsep pembangunan kota berkelanjutan yang menyelaraskan lingkungan alam dan lingkungan buatan manusia sebagai respon terhadap kerusakan lingkungan. Dalam mewujudkan kota hijau, salah satu atributnya yaitu ruang terbuka hijau (RTH) diatur secara ketat dalam UU No. 26 Tahun 2007 tentang Penataan Ruang. Sebanyak $30 \%$ dari luas total kota harus digunakan sebagai ruang terbuka hijau yaitu $20 \%$ sebagai RTH publik dan 10\% RTH sebagai pribadi. Tujuan dari penelitian ini adalah mengidentifikasi luas dan distribusi penggunaan lahan dan RTH eksisting di Kota Yogyakarta, menganalisis kecukupan RTH berdasarkan luas wilayah dan jumlah penduduk, menentukan daerah yang berpotensi dikembangkan menjadi RTH, dan menyusun arahan pengembangan RTH untuk menuju Kota Hijau Yogyakarta. Terdapat beberapa metode yang digunakan dalam penelitian ini, antara lain : interpretasi citra dan analisis kecukupan RTH dihitung berdasarkan luas wilayah dan jumlah penduduk. Hasil penelitian menunjukkan bahwa luas RTH eksisiting adalah 584,45 ha atau $17,78 \%$, yang terdiri dari RTH publik seluas 329,63 ha dan RTH privat seluas 254,82 ha. Berdasarkan luas wilayah, kota Yogyakarta masih memerlukan 390,55 ha ruang terbuka hijau, sedangkan berdasarkan jumlah penduduk, masih kekurangan RTH seluas 220,91 ha. Area berpotensi RTH di Kota Yogyakarta adalah 30,94 ha. Strategi pengembangan RTH Kota Yogyakarta difokuskan untuk mempertahankan dan meningkatkan kualitas RTH yang ada, menambahkan area yang belum termanfaatkan sebagai RTH publik dan mengembangkan koridor hijau. Hal ini menunjukkan bahwa ruang terbuka hijau di kota Yogyakarta tidak mencukupi standar yang dibutuhkan untuk menuju Kota Hijau.
\end{abstract}

\section{Kata kunci : Arahan pengembangan, Kota Hijau, RTH}

Abstract: Green City concept is a concept of sustainable urban development that harmonize the natural environment and man made environment as a response to environmental degradation. Actualizing the green city, one of its attributes green open space is strictly regulated in Law No. 26 Year 2007 about Spatial Planning. The total area of the city 30\% must be used as green open space (RTH), $20 \%$ as public RTH and $10 \%$ as private RTH. The purposes of this research are identifying vast and distribution of land use and RTH existing in Yogyakarta city, analyzing the adequacy of

\footnotetext{
${ }^{1}$ Magister Ilmu Perencanaan Wilayah, Fakultas Pertanian, IPB

${ }^{2}$ Program Studi Ilmu Perencanaan Wilayah, Departemen Ilmu Tanah dan Sumberdaya Lahan, Fakultas Pertanian, IPB

${ }^{3}$ Program Studi Mitigasi Bencana dan Kerusakan Lahan, Departemen Ilmu Tanah dan Sumberdaya Lahan, Fakultas Pertanian, IPB
}

Korespondensi: blubup_lia@yahoo.com 
RTH based on vast territory and total population, determining areas that could potentially be developed for RTH, and arranging development strategy toward to Yogyakarta Green City. Several methods were used in this research, among others : image interpretation and analysis the adequacy of RTH is calculated based on vast territory and total population. The results showed that RTH eksisiting is 584.45 ha or $17.78 \%$, consisting public green open space covering an area of 329.63 ha and private green open space for 254.82 ha. Based on vast territory, Yogyakarta city still needs 390.55 ha of green open space, while based on total population, green open space still lack for 220.91 ha. Potential area in Yogyakarta City is 30.94 ha. RTH development strategy of Yogyakarta City focused on maintaining and increasing the quality of existing RTH, adding unused area as public RTH and developing green corridor. This indicates that green open space in Yogyakarta city is not sufficient based on the standard needed toward Green City.

Keywords : Development Strategy, Green City, Green Open Space (RTH)

\section{PENDAHULUAN}

Perkembangan kota merupakan suatu hal yang tidak dapat dihindari dan salah satu hal krusial yang mempengaruhinya adalah aksesibilitas (Putri dan Zain, 2010). Terbukanya aksesibilitas dari dan ke kota mendorong orang untuk bermigrasi mencari kehidupan yang lebih layak. Semakin padat penduduk kota maka kualitas lingkungan semakin rendah (Todaro dan Smith, 2006) atau disaat pertumbuhan populasi penduduk kota sudah melebihi kapasitas daya dukung lingkungannya. Pembangunan infrastruktur kota untuk memfasilitasi kebutuhan warganya seringkali mengambil ruang hijau sehingga berkurangnya jumlah ruang terbuka hijau yang ada di perkotaan. Para pemilik lahanpun dengan mudah menjual lahannya karena dinilai lebih ekonomis dibandingkan hanya dijadikan lahan pertanian saja.

Salah satu alternatif penyelesaian permasalahan kota yang berkembang di Indonesia adalah dengan menerapkan konsep Kota Hijau (Green City) sebagai bagian dari proses pembangunan dan peremajaan kota. Menurut Ernawi (2012) konsep kota hijau memiliki makna strategis karena dilatarbelakangi oleh beberapa faktor, antara lain pertumbuhan kota yang begitu cepat dan berimplikasi terhadap timbulnya berbagai permasalahan perkotaan seperti kemacetan, banjir, permukiman kumuh, kesenjangan sosial, dan berkurangnya luasan ruang terbuka hijau.

Konsep kota hijau di Indonesia dirumuskan dalam Program Pengembangan Kota Hijau (P2KH). Menurut Kementerian PU (2011) Program Pengembangan Kota Hijau (P2KH) merupakan salah satu langkah Pemerintah Pusat bersama dengan pemerintah provinsi dan pemerintah kota / kabupaten dalam memenuhi ketetapan Undang - Undang Penataan Ruang, terutama terkait pemenuhan luasan RTH perkotaan. Berdasarkan Inmendagri Nomor 14 Tahun 1988 pengertian Ruang Terbuka Hijau kota adalah ruangruang terbuka dalam kota atau wilayah yang lebih luas, baik dalam bentuk areal kawasan maupun dalam bentuk areal memanjang atau jalur dimana di dalam penggunaannya lebih bersifat terbuka, pada dasarnya tanpa bangunan.

Menurut UU No. 26 tahun 2007 luas minimal RTH di wilayah perkotaan agar dapat menjalankan proses-proses ekologis tersebut minimal 30\% dari total luas wilayah kota, terdiri atas RTH publik 20\% dan RTH privat 10\% (Direktorat Jendral Penataan Ruang, Dep. P.U., 2007). Luas RTH kota minimum tersebut adalah untuk menjamin keseimbangan ekosistem kota, baik keseimbangan sistem hidrologi, sistem mikroklimat, maupun sistem ekologis lainnya. RTH sangat diperlukan untuk meningkatkan ketersediaan air dan udara bersih bagi masyarakat serta menciptakan estetika kota (Joga dan Ismaun, 2011).

Salah satu kota yang mengalami pertumbuhan dan perkembangan pesat adalah Kota Yogyakarta yang terjadi dalam beberapa tahun terakhir. Keadaan ini akan terus mengalami perkembangan seiring dengan pertumbuhan penduduk dan aktifitas yang ada di Kota 
Yogyakarta. Secara administratif Kota Yogyakarta adalah Ibukota Provinsi DIY yang berfungsi sebagai pusat pemerintahan, pendidikan, dan perekonomian. Sebagai salah satu kota kuno di Indonesia Kota Yogyakarta merupakan kota yang lahir secara terencana dengan baik dalam pemilihan lokasi hingga rencana tata ruangnya. Pusat kota ini membentuk pola tertentu, pola-pola tersebut adalah alun-alun lor yang merupakan pusat kota dikelilingi Masjid Agung di sebelah baratnya, keraton di sebelah selatannya, dan pasar di sebelah utara

Saat ini kawasan pusat kota mengalami perkembangan pesat dan sudah tidak mampu lagi menampung perkembangan kota yang semakin kompleks. Pada akhirnya RTH akan beralih fungsi menjadi ruang terbangun. Menurut Sitorus et al. (2011) ada beberapa faktor yang mempengaruhi perubahan luas RTH yaitu alokasi RTH dalam RTRW, fasilitas kesehatan, jumlah pendatang, kepadatan penduduk, dan fasilitas pendidikan. Penerapan konsep kota hijau diharapkan mampu menambah Ruang Terbuka Hijau Publik dan Ruang Terbuka Hijau Privat serta merelokasikan kegiatan komersil dan aktifitas umum lainnya sebagai bagian dari upaya menjaga laju pertumbuhan dan kebutuhan ruang kota. RTH publik terdiri dari pembangunan jalur hijau, areal pemakaman, jalur pengaman atau median jalan, kebun binatang, lapangan olah raga, taman kota dan tempat rekreasi serta tempat parkir terbuka, sedangkan RTH privat terdiri dari sawah, taman kantor dan gedung komersil, taman perumahan dan permukiman.

Penelitian ini bertujuan untuk : (1) Mengetahui luas dan persebaran penggunaan lahan dan RTH eksisting di Kota Yogyakarta tahun 2014, (2) Mengetahui luas kecukupan RTH Kota Yogyakarta berdasarkan luas wilayah dah jumlah penduduk, (3) Menentukan area-area berpotensi yang dapat dikembangkan untuk RTH, (4) Menyusun arahan pengembangan RTH menuju Kota Hijau Yogyakarta.

\section{METODE PENELITIAN}

\section{Lokasi dan Waktu Penelitian}

Penelitian dilaksanakan di Kota Yogyakarta, Provinsi Daerah Istimewa Yogyakarta yang mencakup 14 kecamatan yaitu Danurejan, Gedongtengen, Gondokusuman, Gondomanan, Jetis, Kotagede, Kraton, Mantrijeron, Margangsan, Ngampilan, Pakualaman, Tegalrejo, Umbulharjo, dan Wirobrajan dengan luas wilayah 3.250 ha. Penelitian dilaksanakan pada bulan Februari sampai Juli 2014, yang meliputi tahap studi pustaka, pengambilan sampel di lapangan dan pengolahan data.

\section{Jenis dan Sumber Data}

\section{Teknik Analisis Data}

Teknik analisis data yang digunakan untuk menjawab tujuan adalah sebagai berikut:

\section{Interpretasi Citra}

Dalam menganalisis dan mengevaluasi luas dan persebaran, penggunaan lahan eksisting dan RTH eksisting di Kota Yogyakarta dilakukan Interpretasi Citra berupa citra Quickbird terbaru berdasarkan jenis penggunaan lahannya. Citra Quickbird kemudian di digitasi on screen yaitu proses pengubahan data grafis digital dalam struktur data vektor yang disimpan dalam bentuk point, line, atau area. Hasil interpretasi citra kemudian dibandingkan dengan kondisi yang ada di lapangan. Pengecekan lapang dilakukan pada tiap jenis tipe penggunaan lahan, dimana lokasi tersebut mewakili kelas penutupan lahan 
sesuai dengan hasil interpretasi yang telah ditentukan, dan juga pada obyek-obyek yang masih sulit untuk dikenali.

Analisis Kecukupan RTH

Untuk mencapai kecukupan RTH di wilayah Kota Yogyakarta analisis kebutuhan ruang terbuka hijau kota dilakukan dengan tiga pendekatan, yaitu:

1. Kebutuhan RTH Berdasarkan Luas Wilayah

Menghitung kebutuhan RTH untuk mencapai 30\% luas aktual wilayah (dengan proporsi $20 \%$ RTH publik dan $10 \%$ RTH privat) dan membandingkannya dengan luas RTH eksisting.

2. Kebutuhan RTH Berdasarkan Jumlah Penduduk

Menghitung kebutuhan RTH berdasarkan jumlah penduduk yaitu dengan mengalikan antara jumlah penduduk yang dilayani dengan standar luas RTH per kapita sesuai peraturan yang berlaku yaitu $20 \mathrm{~m}^{2} /$ penduduk. Persamaan untuk menentukan luas RTH berdasarkan jumlah penduduk adalah sebagai berikut.

$$
\text { RTH pi }=\text { Pi x k ........ }
$$

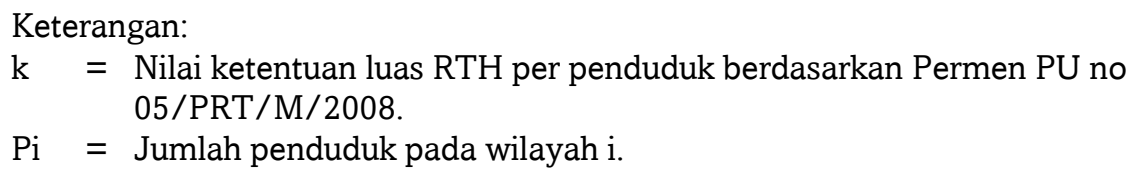

Standar luas RTH per kapita tertera pada Tabel 2. (Peraturan Menteri Pekerjaan Umum No.05 tahun 2008).

Tabel 2. Penyediaan RTH berdasarkan jumlah penduduk

\begin{tabular}{|c|c|c|c|c|c|}
\hline No. & Unit Lingkun & nTipe RTH & $\begin{array}{l}\text { Luas minimal/ } \\
\text { unit }(\mathrm{m} 2)\end{array}$ & $\begin{array}{l}\text { Luas minimal/ } \\
\text { kapita }(\mathrm{m} 2)\end{array}$ & Lokasi \\
\hline 1. & 250 jiwa & Taman RT & 250 & 1,0 & \multirow{3}{*}{$\begin{array}{l}\text { Di tengah lingkungan RT } \\
\text { Di pusat kegiatan RW } \\
\text { Dikelompokkan dengan } \\
\text { sekolah/pusat kelurahan }\end{array}$} \\
\hline 2. & 2.500 jiwa & Taman RW & 1.250 & 0,5 & \\
\hline 3. & 30.000 jiwa & Taman Kelurahan & 9.000 & 0,3 & \\
\hline \multirow[t]{3}{*}{4.} & \multirow[t]{3}{*}{120.000 jiwa } & $\begin{array}{l}\text { Taman } \\
\text { Kecamatan }\end{array}$ & 24.000 & 0,2 & $\begin{array}{l}\text { Dikelompokkan dengan } \\
\text { sekolah/pusat kecamatan }\end{array}$ \\
\hline & & Pemakaman & Disesuaikan & 1,2 & Tersebar \\
\hline & & Taman Kota & 144.000 & 0,3 & Di pusat wilayah/kota \\
\hline \multirow{2}{*}{5.} & \multirow{2}{*}{480.000 jiwa } & Hutan Kota & Disesuaiakan & 4,0 & Di dalam/ kawasan pinggiran \\
\hline & & $\begin{array}{l}\text { Untuk fungsi- } \\
\text { fungsi tertentu }\end{array}$ & Disesuaikan & 12,5 & $\begin{array}{l}\text { Disesuaikan } \\
\text { kebutuhan }\end{array}$ \\
\hline
\end{tabular}

\section{Analisis Area-area Berpotensi Untuk Pengembangan RTH}

Dalam menentukan area yang berpotensi menjadi area RTH digunakan interpretasi citra. Menururut Rahmi et al. (2012) penambahan proporsi RTH secara signifikan dimungkinkan antara lain melalui optimalisasi penataan jalur hijau koridor komersial. Selain itu juga berpotensi untuk dilakukan dalam blok-blok permukiman, dengan bentuk taman lingkungan, taman poket, perkarangan bangunan hunian, maupun jalur hijau jalan lingkungan, melalui strategi pembangunan kembali kawasan (urban redevelopment). Yoga dan Ismaun (2011) merumuskan area yang dapat dijadikan RTH dalam strategi menuju RTH 30\% yaitu area yang sensitif terhadap perubahan harus di konservasi agar fungsi lingkungan tetap terjaga seperti : habitat satwa liar, area yang memiliki keanekaragaman 
tinggi, area genangan dan penampung air, area rawan bencana, tepi sungai sebagai pengaman ekologis, area yang memiliki pemandangan tinggi; koridor jalur hijau seperti : jalur hijau jalan, pedestrian, sempadan sungai, tepian badan air situ dan waduk, sempadan rel kereta api, Saluran Umum Tegangan Tingggi (SUTET); KDH minimal 20\% pada kawasan pengembang (pusat perbelanjaan, hotel, apartemen); taman atap dan dinding hijau pada bangunan.

\section{Penyusunan Arahan Pengembangan RTH}

Penyusunan arahan pengembangan RTH dengan melakukan sintesis terhadap kondisi eksisting, kecukupan RTH dan area berpotensi yang dapat dikembangkan menjadi RTH untuk mencapai konsep Kota hijau. Arahan ini merupakan bentuk pengendalian terhadap perubahan penggunaan pola ruang agar tidak terjadi perubahan ke arah yang tidak diinginkan sekaligus diharapkan menjadi upaya pencegahan dan resolusi dalam mengatasi permasalahan Kota Yogyakarta. Hasil arahan pengembangan RTH menuju Kota Hijau Yogyakarta disajikan dalam bentuk uraian dan dipetakan secara spasial dengan menggunakan Sistem Informasi Geografi.

\section{HASIL DAN PEMBAHASAN}

Persebaran Penggunaan Lahan dan RTH Eksisting di Kota Yogyakarta

Berdasarkan hasil interpretasi Citra Quickbird dan survei lapangan menunjukan bahwa penggunaan lahan Kota Yogyakarta pada tahun 2014 terdiri dari 13 Kawasan, yaitu :

1. Budaya $(1,78 \%)$

2. Industri Kecil dan Menengah (9,69\%)

3. Kesehatan $(1,25 \%)$

4. Kuburan $(1,01 \%)$

5. Pariwisata $(5,45 \%)$

6. Pendidikan $(2,53 \%)$

7. Perdagangan dan jasa $(26,05 \%)$

8. Perkantoran $(4,74 \%)$

9. Pertanian $(2,70 \%)$

10. Permukiman $(40,58 \%)$

11. Rekreasi dan Olah Raga (1,41\%)

12. Ruang Terbuka Hijau atau Sempadan Sungai $(1,43 \%)$

13. Sarana Transportasi $(1,42 \%)$

Penggunaan lahan di Kota Yogyakarta didominasi oleh kawasan permukiman yang menempati hampir setengah bagian dari total wilayah Kota Yogyakarta, tersebar secara merata di tiap kecamatan kecuali Kecamatan Kraton. Kawasan kesehatan, pendidikan, perkantoran, perdagangan dan jasa terdapat di kawasan strategis terutama di sepanjang jalan raya kota. Kawasan industri tersebar di pinggiran kota bagian barat dan selatan. Kecamatan Keraton menjadi kawasan cagar budaya dan pariwisata karena terdapat peninggalan sejarah yaitu keraton kesunanan Yogyakarta. Kawasan sarana transportasi di Kota Yogyakarta hanya terdapat 1 stasiun kereta terletak di tengah kota yag terintegrasi dengan rel kereta dan 1 terminal bus yang terletak di bagian selatan. Posisi stasiun yang strategis dan terhubung dengan bandara menjadikannya pintu gerbang untuk masuk ke Kota Yogyakarta. Kawasan RTH atau sempadan sungai membentuk pola organik mengikuti bentuk sungai. Kawasan lainnya seperti kuburan, pertanian, rekreasi dan olah raga 
terdistribusi secara acak dan tidak terkait dengan kawasan lainnya. Persebaran penggunaan lahan eksisting Kota Yogyakarta tahun 2014 tertera pada Gambar 1.

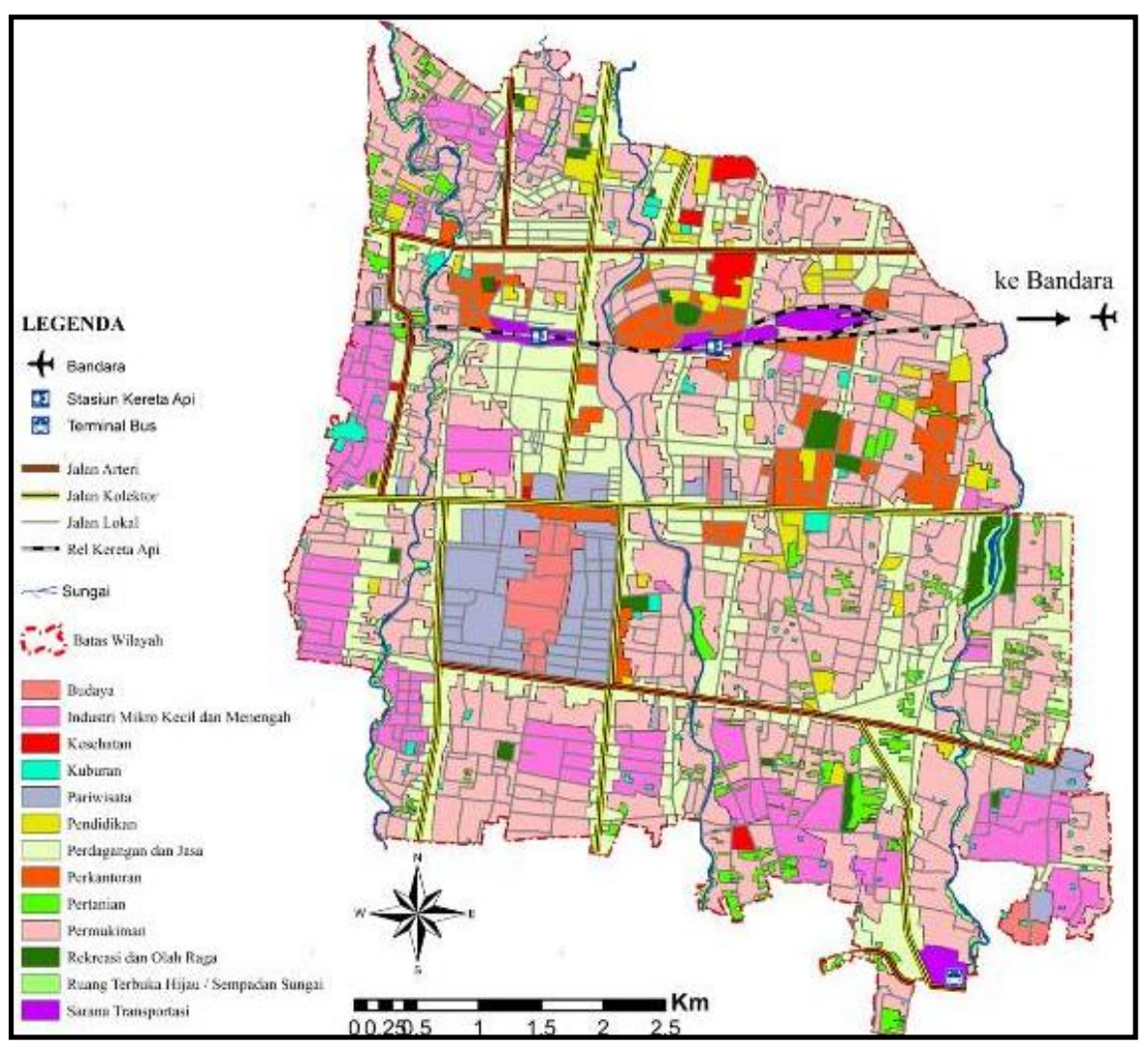

Gambar 1. Peta Penggunaan Lahan Eksisting Kota Yogyakarta tahun 2014

Ruang Terbuka Hijau di Kota Yogyakarta dibagi menjadi 2 bentuk yang terdiri dari 14 jenis penggunaan, yaitu :

1. RTH Publik $(10,03 \%)$ terdiri dari
a. Area Hijau $(4,79 \%)$
b. Jalur Pengaman Jalan $(0,22 \%)$,
c. Kebun Binatang (0,45\%),
d. Lapangan Olah Raga (0,59\%),
e. Parkir Terbuka $(0,95 \%)$,
f. Taman Kota $(0,25 \%)$,
g. Taman Rekreasi $(0,41 \%)$,
h. Pemakaman Umum $(0,94 \%)$,
i. Sempadan Sungai $(1,43 \%)$;

2. RTH Privat $(7,75 \%)$ terdiri dari
a. Lapangan Upacara (0,01\%),
b. Sawah $(2,69 \%)$,
c. Taman Kantor dan Gedung Komersil (4,53\%),
d. Taman Perumahan dan Permukiman (0,52\%). 
Kawasan hijau eksisting didominasi oleh area hijau, taman kantor dan gedung komersil sebesar $10 \%$. Jumlah RTH terbanyak terdapat di Kecamatan Umbulharjo sebesar 165,27 ha. Kawasan pertanian paling luas terletak di kecamatan ini dibandingkan dengan kecamatan-kecamatan lain di Yogyakarta. Pada tahun 2011 luas lahan pertanian sebesar 66,27 ha dan pada tahun 2013 berkurang menjadi 62,47 ha, hanya dalam waktu 2 tahun luas pertanian berkurang sebanyak 3,8 ha (Kota Yogyakarta 2014). Produksi pertanian dari tahun ke tahun tidak pernah optimal dan Kota Yogyakarta dapat mengalami krisis pangan di masa mendatang. Penyusutan lahan pertanian tersebut disebabkan alih fungsi lahan untuk bangunan perumahan, perkantoran, industri dan pertokoan. Hasil perhitungan RTH eksisting tertera pada Tabel 2 .

Tabel 2. Luas RTH eksisting Kota Yogyakarta

\begin{tabular}{lrrrr}
\hline \multicolumn{1}{c}{ Kecamatan } & $\begin{array}{c}\text { Luas Wilayah } \\
\text { (ha) }\end{array}$ & $\begin{array}{c}\text { RTH Publik } \\
\text { (ha) }\end{array}$ & $\begin{array}{c}\text { RTH Privat } \\
\text { (ha) }\end{array}$ & $\begin{array}{c}\text { Total RTH } \\
\text { (ha) }\end{array}$ \\
\hline Danurejan & 110 & 8,57 & 5,35 & 13,93 \\
Gedongtengen & 96 & 10,35 & 1,83 & 12,18 \\
Gondokusuman & 397 & 42,11 & 36,86 & 78,97 \\
Gondomanan & 112 & 9,73 & 8,57 & 18,30 \\
Jetis & 172 & 13,36 & 11,20 & 24,56 \\
Kotagede & 307 & 35,94 & 18,21 & 54,15 \\
Kraton & 140 & 16,28 & 5,90 & 22,18 \\
Mantrijeron & 261 & 26.20 & 29,03 & 55,23 \\
Margangsan & 231 & 17.53 & 16,27 & 33,81 \\
Ngampilan & 82 & 3.61 & 3,71 & 7,32 \\
Pakualaman & 63 & 3,21 & 0,37 & 3,57 \\
Tegalrejo & 291 & 37,81 & 28,40 & 66,27 \\
Umbulharjo & 812 & 86,76 & 78,51 & 165,27 \\
Wirobrajan & 176 & 18,12 & 10,59 & 28,71 \\
Jumlah (ha) & 3250 & 329,63 & 254,82 & 584,45 \\
Jumlah (\%) & 100 & 10,03 & 7,75 & 17,78 \\
\hline
\end{tabular}

Kawasan RTH tersebar secara acak, sempadan sungai yang berupa vegetasi rapat terdapat di sepanjang aliran sungai dan membentuk pola memanjang mengikuti bentuk sungai. Pada pusat kota dengan bangunan padat, didominasi RTH jenis taman kota, taman rekreasi, lapangan olah raga, membentuk pola linear karena dipengaruhi keberadaan keraton. Jalur pengaman jalan terletak di setiap stasiun untuk membatasi akses pengunjung ke area yang dianggap berbahaya. Area ini didominasi oleh kerikil, vegetasi semak dan pohon - pohon berukuran kecil. Pada luar kota jenis RTH yang mendominasi adalah sawah, kebun binatang dan TPU tersebar secara acak.

Secara umum ruang hijau yang ukurannya luas terletak di pinggiran kota dan akan semakin berkurang atau mengecil saat mendekati pusat kota. Ruang hijau privat yang paling banyak adalah dalam bentuk taman kantor dan gedung komersil ruang, berupa taman pasif yang hanya berisi vegetasi hijau tanpa ada aktifitas didalamnya. Taman lingkungan perumahan didominasi oleh tanaman hias dan vegetasi buah-buahan, selain sebagai peneduh hasilnya juga dapat dikonsumsi. Peta RTH eksisting Kota Yogyakarta tahun 2014 terlihat pada Gambar 2.

\section{Kecukupan RTH di Kota Yogyakarta}

\section{Kecukupan RTH Berdasarkan Luas Wilayah}

Undang-Undang Nomor 26 Tahun 2007 tentang Penataan Ruang menetapkan bahwa proporsi RTH pada wilayah perkotaan adalah minimal 30\% dari total luas wilayah, terdiri 
dari $20 \%$ RTH publik dan 10\% RTH privat. Berdasarkan standar tersebut wilayah Kota Yogyakarta yang memiliki luas 3.250 ha, harus memiliki RTH minimum seluas 975 ha, dengan luas RTH publik 650 ha dan RTH privat 325 ha. Berdasarkan hasil interpretasi citra luas RTH eksisting terbesar terdapat di Kecamatan Umbulharjo dengan luas 165,27 ha, jika standar kebutuhan ini dibandingkan dengan kondisi eksisting RTH, maka Kota Yogyakarta memiliki kekurangan RTH seluas 390,55 ha. Seluruh kecamatan kekurangan RTH, RTH publik paling banyak kekurangan terdapat di Kecamatan Umbulharjo seluas 75,64 ha dan yang paling sedikit kekurangannya terdapat di Kecamatan Gedongtengen seluas 8,85 ha. Ada satu kecamatan yang luas RTH privatnya memenuhi standar kebutuhan yaitu di Kecamatan Mantrijeron dengan kelebihan RTH seluas 2,93 ha. Kekurangan RTH privat paling banyak terdapat di Kecamatan Kotagede seluas 12,49 ha. Berkurangnya RTH di Kota Yogyakarta sebagai imbas dari tingginya kebutuhan kota akan permukiman. Lahan yang paling banyak beralih fungsi adalah sawah. Proporsi kecukupan RTH berdasarkan luas wilayah tertera pada Tabel 3.

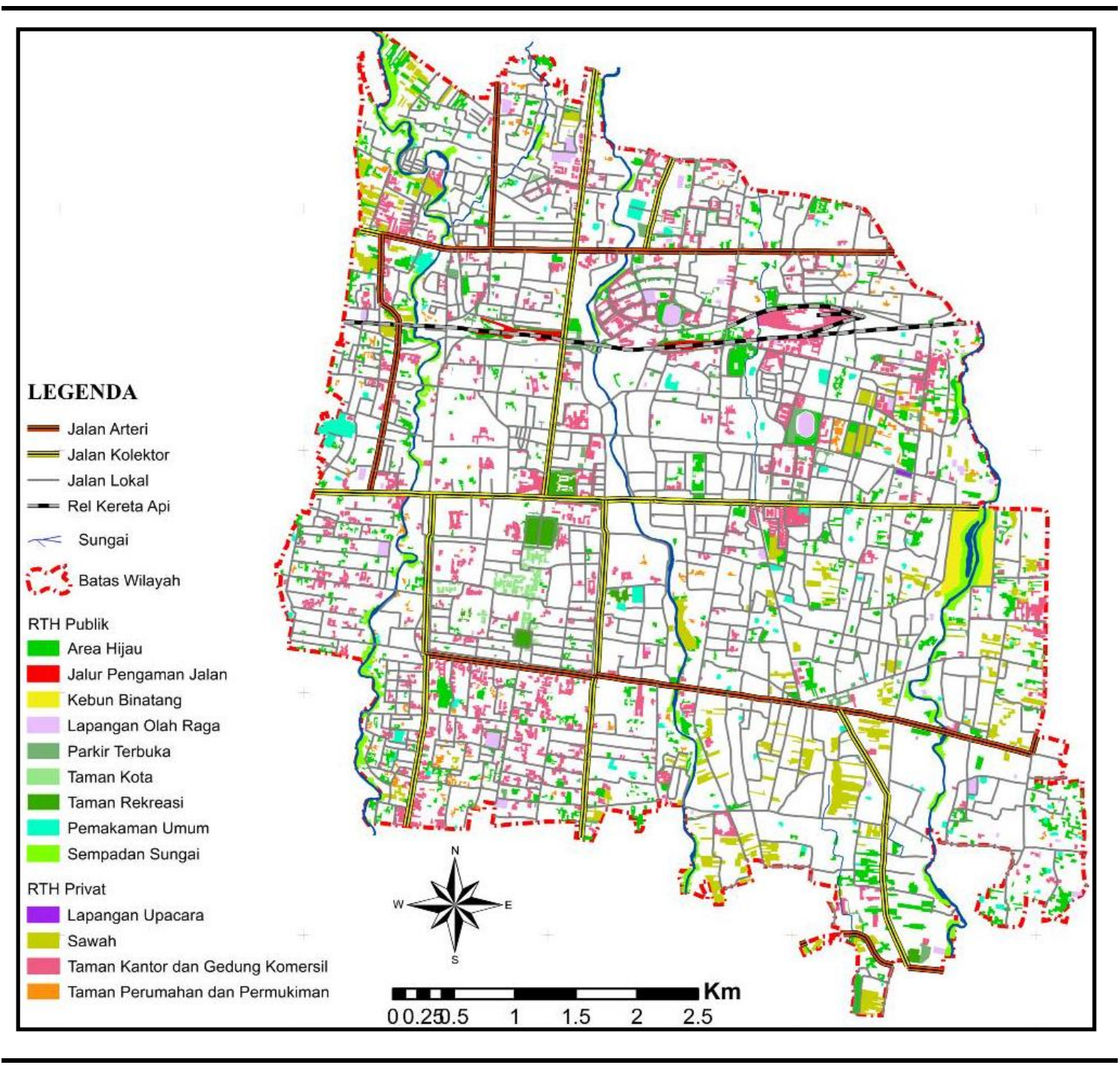

Gambar 2. Peta RTH eksisting Kota Yogyakarta tahun 2014 
Tabel 3. Proporsi Kecukupan RTH Berdasarkan Luas Wilayah

\begin{tabular}{lccccccccc}
\hline \multirow{2}{*}{ Kecamatan } & \multicolumn{3}{c}{ Luas RTH Eksisting (ha) } & \multicolumn{3}{c}{ Kebutuhan RTH (ha) } & \multicolumn{3}{c}{ Kecukupan RTH (ha) } \\
\cline { 2 - 10 } & Publik & Privat & Jumlah & Publik & Privat & Jumlah & Publik & Privat & Jumlah \\
\hline Danurejan & 8,57 & 5,38 & 13,93 & 22 & 11 & 33 & $-13,43$ & $-5,62$ & $-19,07$ \\
Gedongtengen & 10,35 & 1,83 & 12,18 & 19,2 & 9,6 & 28,8 & $-8,85$ & $-7,77$ & $-16,62$ \\
Gondokusuman & 42,11 & 36,86 & 78,97 & 79,4 & 39,7 & 119,1 & $-37,29$ & $-2,84$ & $-40,13$ \\
Gondomanan & 9,73 & 8,57 & 18,3 & 22,4 & 11,2 & 33,6 & $-12,67$ & $-2,63$ & $-15,3$ \\
Jetis & 13,36 & 11,20 & 24,56 & 34,4 & 17,2 & 51,6 & $-21,04$ & -6 & $-27,04$ \\
Kotagede & 35,94 & 18,21 & 54,15 & 61,4 & 30,7 & 92,1 & $-25,46$ & $-12,49$ & $-37,95$ \\
Kraton & 16,28 & 5,90 & 22,18 & 28 & 14 & 42 & $-11,72$ & $-8,1$ & $-19,82$ \\
Mantrijeron & 26,20 & 29,03 & 55,23 & 52,2 & 26,1 & 78,3 & -26 & 2,93 & $-23,07$ \\
Mergangsan & 17,53 & 16,27 & 33,81 & 46,2 & 23,1 & 69,3 & $-28,67$ & $-6,83$ & $-35,49$ \\
Ngampilan & 3,61 & 3,71 & 7,32 & 16,4 & 8,2 & 24,6 & $-12,79$ & $-4,49$ & $-17,28$ \\
Pakualaman & 3,21 & 0,37 & 3,57 & 12,6 & 6,3 & 18,9 & $-9,39$ & $-5,93$ & $-15,33$ \\
Tegalrejo & 37,87 & 28,40 & 66,27 & 58,2 & 29,1 & 87,3 & $-20,33$ & $-0,7$ & $-21,03$ \\
Umbulharjo & 86,76 & 78,51 & 165,27 & 162,4 & 81,2 & 243,6 & $-75,64$ & $-2,69$ & $-78,33$ \\
Wirobrajan & 18,12 & 10,59 & 28,71 & 35,2 & 17,6 & 52,8 & $-17,08$ & $-7,01$ & $-24,09$ \\
\hline Kota Yogyakarta & 329,63 & 254,82 & 584,45 & 650 & 325 & 975 & $-320,36$ & $-70,17$ & $-390,55$ \\
\hline
\end{tabular}

\section{Kecukupan RTH Berdasarkan Jumlah Penduduk}

Peraturan Menteri Pekerjaan Umum No.05/PRT/M/2008 menetapkan standar kebutuhan RTH berdasarkan jumlah penduduk adalah $20 \mathrm{~m}^{2} /$ kapita. Data BPS menunjukkan bahwa jumlah penduduk Kota Yogyakarta pada tahun 2013 adalah 402.679 jiwa, sehingga Kota Yogyakarta membutuhkan RTH seluas 805,36 ha. Rata-rata laju pertumbuhan penduduk adalah 0,69\% per tahun. Proyeksi jumlah penduduk untuk tahun 2029 dilakukan dengan menggunakan rumus bunga berganda, perkiraan jumlah penduduk tahun 2029 adalah 449.511 jiwa. Jumlah penduduk yang terus meningkat akan di iringi dengan peningkatan kebutuhan ruang. Pada tahun 2029 proyeksi kebutuhan RTH adalah 899.02 ha. Jika dibandingkan dengan RTH Eksisting terdapat kekurangan seluas 314,57 ha. Seluruh kecamatan di Kota Yogyakarta kekurangan RTH, yang paling banyak kekurangan adalah Kecamatan Margangsan seluas 33,09 ha. Proporsi Kecukupan RTH Berdasarkan Jumlah Penduduk tahun 2029 tertera pada Tabel 4.

Tabel 4. Proporsi Kecukupan RTH Berdasarkan Jumlah Penduduk pada tahun 2029

\begin{tabular}{lrrrrr}
\hline \multirow{2}{*}{ Kecamatan } & \multirow{2}{*}{$\begin{array}{c}\text { Proyeksi Jumlah } \\
\text { Penduduk (jiwa) }\end{array}$} & \multirow{2}{*}{$\begin{array}{c}\text { Kepadatan } \\
\text { Penduduk }\end{array}$} & \multicolumn{3}{c}{ Kecukupan RTH (ha) } \\
\cline { 5 - 6 } & & jiwa/ha) & Kebutuhan & Eksisting & \multicolumn{1}{c}{ Selisih } \\
\hline Danurejan & 20946 & 190 & 41,89 & 13,93 & $-27,96$ \\
Gedongtengen & 19628 & 204 & 39,26 & 12,18 & $-27,08$ \\
Gondokusuman & 51724 & 130 & 103,45 & 78,97 & $-24,48$ \\
Gondomanan & 14877 & 133 & 29,75 & 18,3 & $-11,45$ \\
Jetis & 26782 & 156 & 53,56 & 24,56 & $-29,00$ \\
Kotagede & 36822 & 120 & 73,64 & 54,15 & $-19,49$ \\
Kraton & 19953 & 143 & 39,91 & 22,18 & $-17,73$ \\
Mantrijeron & 36149 & 139 & 72,30 & 55,23 & $-17,07$ \\
Margangsan & 33450 & 145 & 66,90 & 33,81 & $-33,09$ \\
Ngampilan & 18638 & 227 & 37,28 & 7,32 & $-29,96$ \\
Pakualaman & 10642 & 169 & 21,28 & 3,57 & $-17,71$ \\
Tegalrejo & 41032 & 141 & 82,06 & 66,27 & $-15,79$ \\
Umbulharjo & 90502 & 111 & 181,00 & 165,27 & $-15,73$ \\
Wirobrajan & 28366 & 161 & 56,73 & 28,71 & $-28,02$ \\
\hline Kota Yogyakarta & 449511 & 138 & 899,02 & 584,45 & $-314,57$ \\
\hline
\end{tabular}




\section{Area Yang Berpotensi Untuk Dikembangkan Menjadi RTH}

Berdasarkan hasil interpretasi citra, Kota Yogyakarta didominasi oleh lahan terbangun sehingga sangat sulit untuk menemukan lahan yang dapat dimanfaatkan sebagai RTH. Potensi 1 adalah lahan milik pemerintah berupa jalur pemisah jalan disepanjang jalur arteri dan kolektor yang dapat dijadikan jalur hijau. Potensi 2 adalah lahan milik warga berupa lahan-lahan kosong bekas bangunan atau tanah kosong yang belum termanfaatkan. Pemerintah daerah dapat membeli lahan-lahan ini karena lebih efisien dibandingkan harus membeli lahan yang terdapat bangunan. Potensi 3 adalah sempadan sungai dengan lebar $30 \mathrm{~m}$ di kiri dan kanan sungai yang seharusnya bebas dari lahan terbangun. Potensi 3 adalah rencana jangka panjang kerena memerlukan usaha dan biaya yang banyak karena harus membebaskan tanah warga. Walaupun luas RTH eksisting sudah ditambah dengan area berpotensi RTH jumlahnya hanya 710,47 (21,62\%) masih kurang dari standar kebutuhan yang harus dipenuhi untuk menuju Kota Hijau yaitu 30\%. Perhitungan rinci area berpotensi tertera pada Tabel 5 dan peta area berpotensi RTH terlihat pada Gambar 3.

Tabel 5. Luas Area Berpotensi RTH di Kota Yogyakarta

\begin{tabular}{|c|c|c|c|c|}
\hline Kecamatan & Eksisting & Potensi 1 & Potensi 2 & Potensi 3 \\
\hline Danurejan & 13,93 & 0.37 & 0.51 & 4,51 \\
\hline Gedongtengen & 12,18 & 0 & 0.92 & 2,48 \\
\hline Gondokusuman & 78,97 & 1.49 & 2.62 & 7,26 \\
\hline Gondomanan & 18,30 & 1.16 & 0.31 & 4,01 \\
\hline Jetis & 24,56 & 1.82 & 1.65 & 9,22 \\
\hline Kotagede & 54,15 & 0.44 & 0 & 4,23 \\
\hline Kraton & 22,18 & 1.19 & 0.22 & 0 \\
\hline Mantrijeron & 55,23 & 0.71 & 1.33 & 3,66 \\
\hline Margangsan & 33,81 & 1.45 & 0.62 & 8,87 \\
\hline Ngampilan & 7,32 & 0.57 & 0.36 & 4,65 \\
\hline Pakualaman & 3,57 & 0.51 & 0.61 & 1,92 \\
\hline Tegalrejo & 66,27 & 1.72 & 0.94 & 19,53 \\
\hline Umbulharjo & 165,27 & 3.33 & 4.35 & 20,04 \\
\hline Wirobrajan & 28,71 & 0.86 & 0.87 & 4,7 \\
\hline Jumlah (ha) & 584,45 & 15.62 & 15.32 & 95,08 \\
\hline Jumlah (\%) & 17,78 & 0.48 & 0.47 & 2,89 \\
\hline
\end{tabular}

\section{Arahan Pengembangan RTH menuju Kota Hijau Yogyakarta}

Arahan RTH terdiri dari sebaran luas, bentuk dan fungsi RTH. Kondisi eksisting digunakan untuk mengetahui kuantitas, kualitas dan fungsi peruntukan RTH yang ada di Kota Yogyakarta. Kecukupan RTH digunakan untuk menghitung standarisasi jumlah RTH yang dibutuhkan suatu kota. Area yang berpotensi RTH digunakan untuk menentukan area mana saja yang dapat digunakan sebagai RTH. RTRW Kota Yogyakarta digunakan untuk melihat apakah suatu area sudah sesuai peruntukannya.

Luas RTH eksisting Kota Yogyakarta adalah 584,45 ha. RTH ini merupakan RTH alami dan binaan sehingga perlu dipertahankan dan ditingkatkan kualitasnya. RTH ini sebagian berbentuk kawasan seperti area hijau, area olahraga, taman kota, taman kantor, lahan pertanian dan sebagian lagi berbentuk jalur pengaman jalan dan jalur sempadan sungai. Fungsi yang dominan di RTH ini adalah fungsi ekologis, estetika, sosial dan ekonomi. 


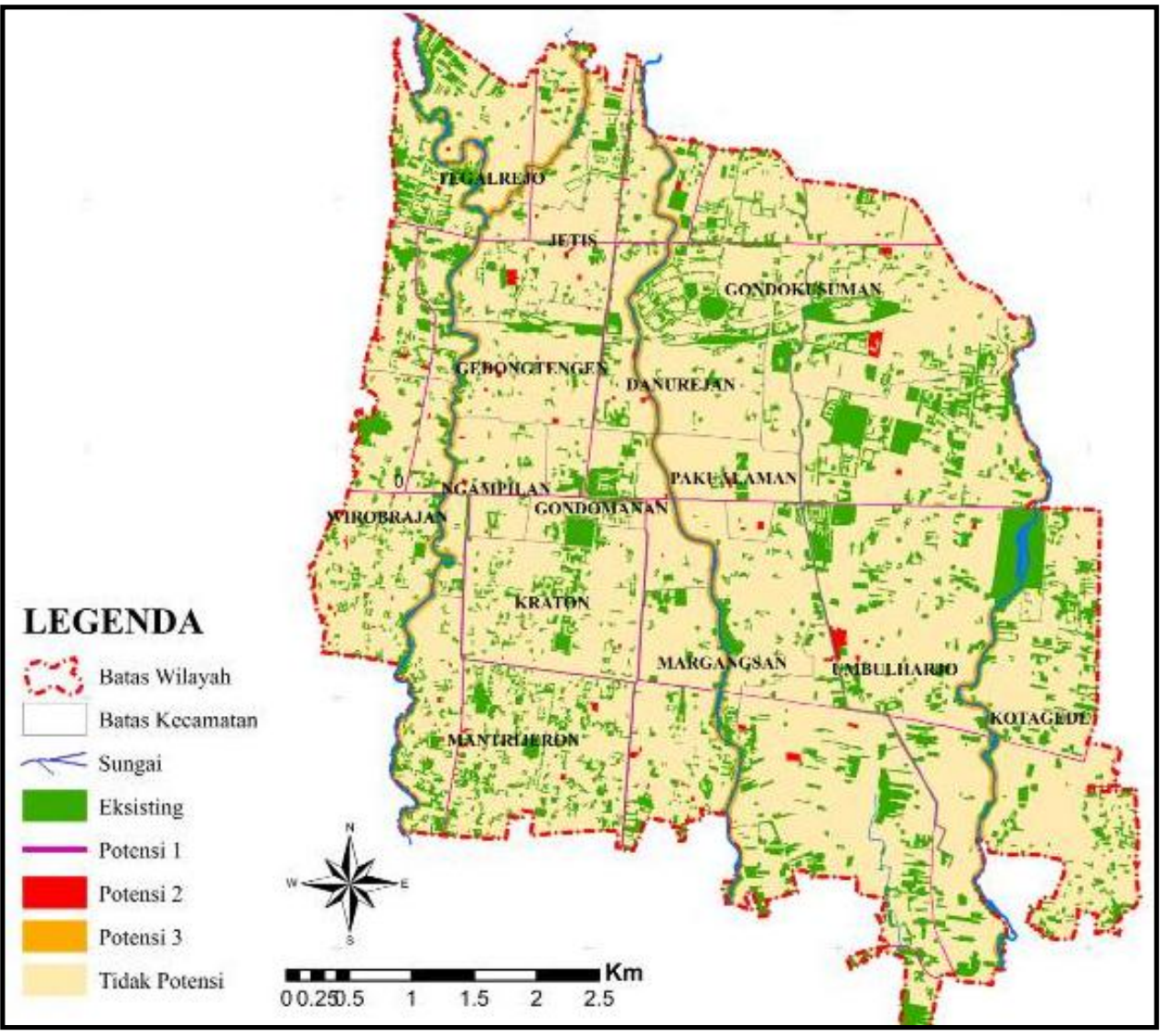

Gambar 2. Area Berpotensi RTH

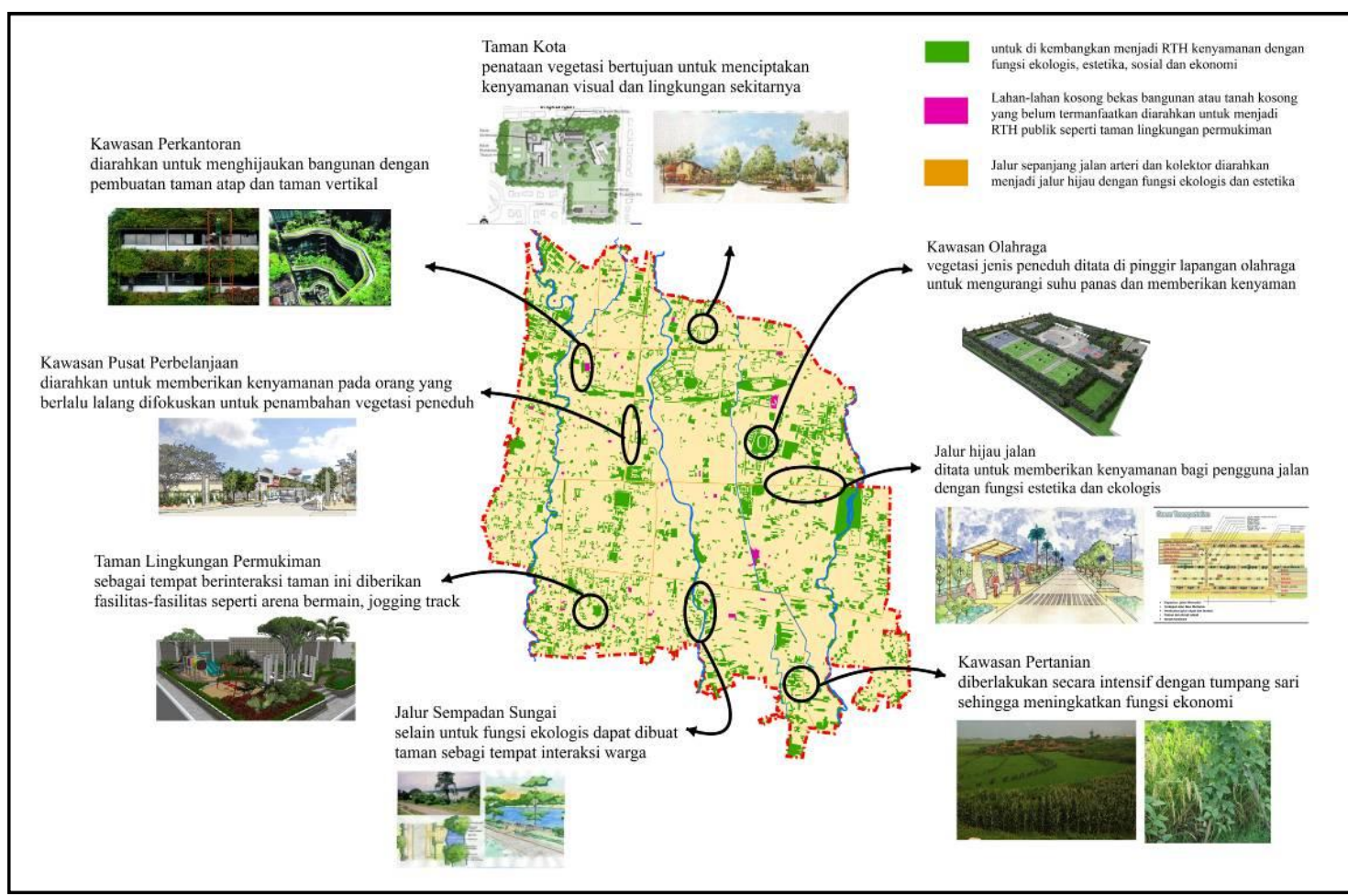

Gambar 3. Arahan Pengembangan RTH Kota Yogyakarta 
Penambahan RTH di kota ini dilakukan pada lahan-lahan kosong bekas bangunan atau tanah kosong yang belum termanfaatkan seluas 15,32 ha. Area ini diarahkan untuk menjadi RTH publik seperti taman lingkungan permukiman yang di fasilitasi dengan area bermain terutama untuk fungsi sosial dan estetika. Penambahan jalur hijau jalan seluas 15,62 ha di sepanjang jalan arteri dan kolektor dengan fungsi ekologis dan estetika terutama sebagai peneduh dan penyerap polusi udara. Banyaknya area terbangun dan mahalnya harga lahan di Kota Yogyakarta sehingga sangat sulit untuk melakukan penambahan area RTH, maka pengembangan RTH di kota ini di fokuskan pada pengembangan RTH kenyamanan. Arahan pengembangan RTH Kota Yogyakarta disajikan pada Gambar 3.

\section{KESIMPULAN}

Penggunaan lahan eksisting di Kota Yogyakarta didominasi oleh permukiman seluas 1333,75 ha atau $40.58 \%$ dari luas total wilayah Kota Yogyakarta. Permukiman ini tersebar merata di seluruh Kota Yogyakarta. RTH eksistingnya seluas 584,45 ha $(17,78 \%)$ terdiri dari RTH publik seluas 329,63 ha $(10,03 \%)$ dan RTH privat seluas 254,82 ha $(7,75 \%)$. Pada pusat kota, RTH tersebar secara linear umumnya berupa RTH publik seperti taman kota dan rekreasi, sedangkan di pinggiran kota RTH tersebar secara acak didominasi oleh RTH privat seperti sawah.

Kebutuhan RTH Kota Yogyakarta berdasarkan luas wilayah adalah seluas 975 ha dan berdasarkan jumlah penduduk 805,36 ha. Kecukupan RTH berdasarkan luas wilayah masih terdapat kekurangan RTH publik seluas 320,36 ha dan RTH privat seluas 70,17 ha, sedangkan berdasarkan jumlah penduduk masih kekurangan RTH seluas 220,91 ha. Saat ini kecukupan RTH berdasarkan jumlah penduduk yang dapat tercukupi adalah di Kecamatan Umbulharjo, yaitu terdapat kelebihan seluas 3,12 ha. Pada proyeksi tahun 2029 semua kecamatan di Kota Yogyakarta akan kekurangan RTH karena semakin meningkatnya jumlah penduduk sehingga akan semakin banyak ruang yang dibutuhkan.

Area yang berpotensi untuk dijadikan RTH adalah seluas 126,02 ha atau 3,84\%. Area potensi 1 berupa jalur hijau jalan hanya terdapat 15,62 ha $(0,48 \%)$, area potensi 2 yang berupa lahan kosong seluas 15,32 ha $(0,47 \%)$ dan area 3 berupa sempadan sungai seluas 95,08 ha $(2,89 \%)$. Luas total RTH hanya mampu mencapai 710,47 ha atau $21,62 \%$. Hal ini menunjukkan bahwa RTH di Kota Yogyakarta masih jauh dari standar kebutuhan yang harus dipenuhi untuk menuju Kota Hijau yaitu 30\%.

Arahan pengembangan RTH Kota Yogyakarta untuk menuju Kota Hijau adalah sebagai berikut :

- Mempertahankan RTH eksisting seluas 584,45 ha yang berupa area hijau, taman kota dan sempadan sungai.

- Menambah RTH seluas 126,02 ha yang ditujukan untuk membangun RTH publik seperti jalur hijau jalan, taman lingkungan permukiman dan merefungsi sempadan sungai.

- Pengembangan RTH di kota ini di fokuskan pada pengembangan RTH kenyamanan seperti meningkatkan kualitas RTH eksisting dengan penambahan vegetasi terutama jenis peneduh dan menghijaukan bangunan dengan roof garden atau vertical garden.

\section{SARAN}

1. Tingginya alih fungsi lahan di Kota Yogyakarta memerlukan adanya pengaturan dan pengawasan oleh pemerintah melalui BPN dan Dinas Cipta Karya dalam pengurusan IMB juga sosialisasi mengenai penetapan $\mathrm{KDH}$ di lingkungan permukiman bagi para warganya. 
2. Penetapan luas RTH 30\% pada RTRW 2010-2029 Kota Yogyakarta perlu ditinjau kembali, karena melihat kondisinya saat ini cukup sulit untuk di implementasikan terutama di kota-kota besar.

3. Meningkatkan kesadaran masyarakat akan lingkungan melalui gerakan-gerakan yang mampu mengajak masyarakat untuk dapat peduli terhadap lingkungan. Salah satunya adalah dengan memberikan insentif bagi warga yang mempertahankan dan melakukan penghijauan di sekitar tempat tinggalnya.

\section{DAFTAR PUSTAKA}

[BPS] Badan Pusat Statistik Kota Yogyakarta. 2014. Kota Yogyakarta dalam Angka. Yogyakarta (ID): BPS.

[BPS] Badan Pusat Statistik Umbulharjo. 2014. Umbulharjo dalam Angka. Yogyakarta (ID): BPS.

[Depdagri] Departemen Dalam Negeri. 1998. Intruksi Menteri Dalam Negeri No. 14 Tahun 1998 Tentang Penataan Ruang terbuka Hijau Wilayah Perkotaan. Jakarta (ID): Menteri Dalam Negeri.

Direktorat Jendral Penataan Ruang Departemen Pekerjaan Umum. 2007. Undang-undang No 26 tahun 2007 Tentang Penataan Ruang. Jakarta (ID): Direktorat Jendral Penataan Ruang Menteri Pekerjaan Umum.

Direktorat Jendral Penataan Ruang Departemen Pekerjaan Umum. 2008. Peraturan Menteri pekerjaan Umum Nomor: 05/PRT/M/2008 Tentang Pedoman Penyediaan dan Pemanfaatan Ruang Terbuka Hijau di Kawasan Perkotaan. Jakarta (ID): Direktorat Jendral Penataan Ruang Menteri Pekerjaan Umum.

Ernawi IS. 2012. Gerakan Kota Hijau: Merespon Perubahan Iklim dan Pelestarian Lingkungan. Bulletin Tata Ruang. (Januari-Pebruari 2012): 4-7.

Joga N, Ismaun I. 2011. RTH 30\%! Resolusi (Kota) Hijau. Jakarta (ID): PT Gramedia Pustaka Utama.

Kementerian Pekerjaan Umum. 2011. Program Pengembangan Kota Hijau (P2KH) Panduan Pelaksanaan. Jakarta (ID): Kementerian Pekerjaan Umum.

Putri P, Zain AFM. 2010. Analisis Spasial dan Temporal Perubahan Luas Ruang Terbuka Hijau di Kota Bandung. Jurnal Lanskap Indonesia 2 (2): 115-121.

Rahmy WA, Faisal B, Soeriaatmadja AR. 2012. Kebutuhan Ruang Terbuka Hijau Kota pada Kawasan padat, Studi Kasus di Wilayah Tegallega, Bandung. Jurnal Lingkungan Binaan Indonesia 1 (1): 27-38.

Sitorus SRP, Aurelia W, Panuju DR. 2011. Analisis Perubahan Luas Ruang Terbuka Hijau dan Faktor-Faktor yang Mempengaruhinya di Jakarta Selatan. Jurnal Lanskap Indonesia, 2 (1): 15-20.

Todaro MP, Smith S.C. 2006. Pembangunan Ekonomi. Terjemahan. Edisi kesembilan. Munandar, H (penterjemah). Jakarta (ID): Erlangga. 